\title{
ENGLISH LANGUAGE LEARNING MOTIVATION OF STUDENTS AT THE SAPIENTIA HUNGARIAN UNIVERSITY OF TRANSYLVANIA IN MIERCUREA CIUC
}

\author{
ZSUZSANNA DÉGI \\ Department of Humanities, Faculty of Economics, Socio-Human Sciences \\ and Engineering, Sapientia Hungarian University of Transylvania \\ P-ta Libertatii nr. 1, Miercurea Ciuc, 530104 Romania \\ E-mail address: degizsuzsanna@uni.sapientia.ro \\ ORCID: https://orcid.org/0000-0002-2845-3883 \\ ORSOLYA KOVASCH \\ Department of Humanities, Faculty of Economics, Socio-Human Sciences \\ and Engineering, Sapientia Hungarian University of Transylvania \\ P-ta Libertatii nr. 1, Miercurea Ciuc, 530104 Romania \\ E-mail address: 1kovaschorsolya@gmail.com \\ ORCID: https://orcid.org/0000-0001-5134-3052
}

\begin{abstract}
Aim. The present research aims to explore the English language learning motivation of students at the Sapientia University, Faculty of Economics, Socio-Human Sciences and Engineering, Miercurea-Ciuc (Csíkszereda).

Method. 103 students took part in the exploratory research where an online questionnaire containing 50 statements was used to find out students' motivations to learn English, focusing on seven different motivational factors (instrumentality, desire to become a global citizen, ideal foreign language self, desire for self-satisfaction, attitudes towards learning English, cultural integration and ought-to foreign language self).

Results and conclusion. Results show that instrumental motivation has a strong effect on the surveyed students as they are highly motivated by the idea of getting a well-paying job with the help of their English language knowledge. Moreover, we also found out that participant students do not want to integrate within a native Englishspeaking community; they do not want to speak the language as native speakers, they rather aim to become global citizens with English.

Cognitive value. The results of this exploratory research might offer valuable insight into students' language learning motivation. Therefore, the study might be helpful for university teachers to have detailed information and a clearer picture of their students' language learning motivations.
\end{abstract}

Key words: motivation, university students, Transylvania, global citizen 


\section{INTRODUCTION}

$\mathrm{M}$ otivation, besides attitude, aptitude and many others, is one of the most important factors that affect foreign language learning. Motivation is generally understood as the wishes and desires that a language learner has towards the target language; at the same time, multiple studies have come to the conclusion that those who feel motivated to learn something will more likely succeed in it than those who are not motivated enough or at all.

Nowadays all students learn English in Romania starting from the first grade of school and all students of the Sapientia university learn English (in a few cases German) for a minimum of four semesters as a compulsory subject. Besides the obligatory nature of learning English as a foreign language, university students are motivated by different factors to learn this foreign language. Each and every student goes to the university's language classes with different levels of motivation, which can change over time as motivation is not a stable state but rather a dynamic process with its turns and changes. There are many other aspects that influence the language learning process, like the language learner's age, aptitude, attitude and environment, but in the present paper, the focus is on the types of student motivations and the different factors that influence this motivation.

According to Kamo Chilingaryan and Rimma Gorbatenko (2015), motivation is a desire to achieve a goal plus the energy invested in order to achieve it. When we hear the word "motivation," what immediately comes to our minds are goals, effort, desire, energy, active involvement, persistence, etc. Successful learning occurs when a student reaches or exceeds his/her initial goal. Language learning and also language maintenance require a lot of effort and patience; therefore, motivation refers not only to the beginning of the language learning process but also to the effort and hard work put into the learning process to turn it into a sustainable process (Kontráné Hegybíró, Csizér, \& Piniel, 2015).

We think we understand the term motivation and we often use it when we are talking about language learning (both successful and unsuccessful). In fact, motivation covers so many variables and factors that we may have the feeling that people talk about completely different things when they use this term. Motivation has been treated as emotion and cognition, as some individual differences, as a process, as the sum of internal and external factors in language learning. The only thing that researchers may agree upon is that motivation is "why people behave as they do" (Dörnyei, 2014, p. 519).

Ema Ushioda (2010) argues that in foreign language acquisition a person cannot be separated from the environment in which he/she lives. Studying foreign language motivation, we have to take both environmental and individual factors into account. Moreover, Zoltán Dörnyei (2014) argues that human behaviour can be formed in many ways and ideas such as power, peace, faith, family, freedom and love can motivate us internally, which simultaneously makes the concept of motivation even more complex. What makes the understanding of the term easier is that we know when we are motivated and when 
we are not, and we are able to differentiate motivational experiences from emotional experiences (like happiness, sadness, anger) (Dörnyei, 2014).

Taking all the above into account, we believe that foreign language learning motivation is rather an umbrella term since it is abstract and complex, covering a lot of language learning related factors and behaviours. Motivation stands for the desire to learn something new and the hope that what we do is effective and will have the desired outcome. Motivation is what keeps us going and working to achieve our aims, the driving force behind our efforts.

\section{THE COMPLEXITY OF MOTIVATION}

Since the 1950s motivation has become a very important research topic within foreign language acquisition, but somehow, according to Ushioda (2010), motivational research has been kept in a marginalised position compared to other studies in linguistics. Motivation is the key to differentiate first language acquisition from additional language acquisition. Motivation does not have such an important role in the case of infants learning their mother tongue, but later in life, motivation is the factor that shows how enthusiastic and successful people learn other languages (Ushioda, 2010).

Since the 1960s several books and studies have been published on the topic of language learning motivation. Dörnyei (2005) divided foreign language motivation research into three stages: a) the social-psychological period, b) the cognitive-situated period, and c) the process-oriented period. The current period is referred to as the socio-dynamic period. This period is framed by Dörnyei's theory of the ideal self. Ushioda (2014) states that, in the past 50 years, research on language learning motivation has focused on the future dimension of motivation. Lately, motivation has been combined with one's desires and with their imagined future self, for instance, Dörnyei formulated the theory of the Motivational Self System (Dörnyei, 2005, 2009). Here, the focus is on who someone can become in the future, and how their target language will help them reach their ideal self, which can be personally desired and can differ from one person to another. In 2005 Dörnyei started a discussion on motivation from a more psychological approach. The basis of the new initiative is the "important psychological concept of possible selves" (Markus \& Nurius, 1986, as cited in Dörnyei, 2005, p. 101). The theory of possible selves is a comprehensive and complex theory, which shows the future/futuristic ideas that people have about themselves, the way they would like to be or what they do not want to be. The possible selves or future-self theory comprises three different components:

- the ideal self: the characteristics that someone wants to own (hopes, wishes);

- the ought-to self: the qualities, skills that someone thinks they ought to have (obligations, responsibilities, e.g. family obligations);

- the students' learning environment: the classroom, the teacher, the curriculum, the group (Dörnyei, 2014). 
In the past ten years, several researchers have studied foreign language learning self-system in different learning environments. Erika-Mária Tódor (2009) applied Dörnyei's concept of possible selves to her study on language learning motivation conducted in Romanian schools with Hungarian language of instruction. Tódor focused on the differences between the motivation to learn a foreign language and motivation to learn the state language. The results of the study show that students' ideal L2 self is highly connected to the English language (94\%), followed by Romanian (81\%) and German (42\%). Looking at obligations and responsibilities (ought-to self), it emerges that $79 \%$ of participants consider language learning important because they will need it in the future, 70\% mention the successful exams and 68\% emphasise the importance of language knowledge. Adrienn Fehér (2012) also found in her research that the ought-to self plays a significant role when she conducted a study at the Danube Bend on seventh and eighth graders' motivation. The data show that at this age peer recognition and acknowledgement is very important and that learners try to fit into others' expectations even in language learning. Unlike Tódor and Fehér, in their research involving western Hungarian high school students, Dóra Galántai and Kata Csizér (2009) found that the ought-to L2-self motivational factor does not significantly influence Hungarian students' language learning motivation.

In the last few years, foreign language motivation research has been focusing on "the situated complexity of the L2 motivation process and its dynamic interaction with a multiplicity of internal, social, and contextual factors in our modern and increasingly globalised world" (Dörnyei, 2014, p. 529). We have to take into consideration that the modern foreign language learners and their environment have changed a lot; today, the language learner's ethnicity, sociocultural environment and identity are the foci of most studies.

In terms of the types of motivation, we distinguish instrumental and integrative motivation. Instrumental motivation refers to the desire to learn a language in order to complete a certain task such as getting a job, reading foreign articles, passing exams, etc. Hence, instrumental motivation occurs when the aim of language learning is to achieve a certain reward, prize or promotion (see Gardner, 2001; Dörnyei, 2005; Ushioda, 2010). Integrative motivation stands for the desire to learn a language with the aim of communicating with people of another culture and to identify to a certain degree with speakers of the foreign language. Integrative motivation is mainly the positive attitude of the language learner towards the language speaking community and the desire to integrate into the group (Gardner, 1959, as cited in Fernández Orío, 2013).

María Carrió-Pastor and Eva Mestre Mestre (2013) found that students who were identified as having integrative motivation in studying a language were the ones who ranked higher on their level of motivation. Moreover, students with instrumental motivation were mostly interested in learning everyday communication and language use rather than the structure and grammar of a language. However, one single type of motivation is rarely displayed by language learners; they are more likely to have both. In their study, Dóra Török 
and Kata Csizér (2007) focused on the language learning motivation of those undergraduate students who study languages at a Hungarian university. The results of their study show that the respondents would like to use English in the future and at the same time, they desire to reach an almost native-level of English knowledge. The same research shows that those students who major in English are motivated mainly by two motivational factors: the desire for intercultural communication (the use of media in English) and at the same time, the desire to reach a native-like level in English (ideal L2 self). Furthermore, their answers show that they are not significantly influenced by the integrative motivational factors. Zsuzsanna Dégi (2012) found that students might learn languages for different reasons. For example, in her study on Transylvanian Hungarian learners, she found that while French was learnt for pleasure (integrative motivation), English was considered to be useful in many areas, such as getting a good job or building an international career (Dégi, 2012).

In 2005 Dörnyei stated that there is a need to reinterpret the concept of integrativeness. The problem with integrativeness is that in the lack of the foreign language speaking community being close to the language learner (which happens very often), the identification with the community may be reduced to the cultural (and sometimes to the intellectual) characteristics related to the respective foreign language. In this case, English can be interpreted as a "nonparochial, cosmopolitan, globalised world citizen identity" (Dörnyei, 2005, p. 97). The World English identity can be connected also with the instrumental aspects because the language is used in many developed industries (Dörnyei, 2005). This is the reason why integrative and instrumental motives have been lately blending (Kimura, Nakata, \& Okumura, 2001, as cited in Dörnyei, 2005).

Research on global language identity (Dörnyei, 2005) is comprised of psychological studies analysing the effects of globalisation. Jeffrey J. Arnett (2002, p. 777, as cited in Dörnyei, 2005, p. 97) claims that "most people now develop a bicultural identity, in which part of their identity is rooted in their local culture while another part stems from an awareness of their relation to the global culture." By watching television and using the Internet, youngsters establish a global identity and get a sense of belonging to a culture. The concept of imagined community was created by Bonny Norton (2001, as cited in Dörnyei, 2005, p. 98), and it refers to a community that was constructed by personal experiences, factual knowledge and imaginary elements of the future. This concept can be interpreted as a desire to belong to an imagined foreign language community. As a result, Dörnyei argues that the term 'integrative' should be abandoned and the focus should be put on the language learner's self-concept.

Factors such as age, aptitude, intelligence, cognitive style, motivation and personality all influence foreign language acquisition. In the 1990s, Robert Gardner and Paul Tremblay (1994, as cited in Dörnyei, 2003) found that the classroom environment has a stronger motivational influence than it had been thought before, so researchers started to pay more attention to the motivational power of the learning context. Therefore, the larger social and educational context, the nature of English classes, teachers, family and the surrounding milieu 
can all have an influence on learners' motivation. Task motivation can be a key factor in foreign language motivation research, especially in classroom learning. Tasks are important in planning classroom activities, in a way that these activities can make a significant difference in the attitudes of the students towards language learning (Dörnyei, 2003). According to Florentina Taylor's study (2013), Romanian teenagers feel motivated if they see that their teacher is motivated and has a positive attitude. It boosts the student's motivation when they feel that the teacher is interested in the subject he/she teaches.

In her research, Fehér (2012) discusses motivation in language classes, looking for factors that affect primary school language learner's the most. Her findings show that the researched students were generally motivated for language learning. The students marked that they felt that it was important to their parents that they learn a language and that they were supported by them. The results of the study carried out by Galántai and Csizer (2009) show that the respondents were satisfied with their language learning experiences in high school. Previous research indicated (Kormos \& Csizér, 2005, as cited in Galántai \& Csizér, 2009) that the parents of the respondents had a positive and quite strong influence on their foreign language learning.

Another major factor influencing motivation is attitude. Ellis (1985, as cited in Khasinah, 2014) clarifies that attitude consists of positive and negative feelings that a language learner has towards the target language. Attitude is influenced by the language learner's culture, the target language's culture and often by the teacher. Attitude can have a negative and a positive influence on the interest in foreign languages (Getie, 2020). There are many studies about the role of attitude and motivation in foreign language acquisition. The research conducted by Gardner and Lambert (1972, as cited in Bíró, 2012) shows that the attitude towards the speakers of the target language is the basis of learning that language (Bíró, 2012). Gardner and Lambert (1985, as cited in Khasinah, 2014) categorised the types of attitudes into attitudes towards the target language speaking community and people, attitudes towards learning (in general and towards language learning as well), and attitudes towards languages.

An interesting case study by Alba Acre García (2016) in the Netherlands focuses on the effect of motivational factors on foreign language learning. The results from the motivational questionnaires clearly show that these respondents had a positive attitude towards learning English. In their research on Western Hungarian high school students, Galántai and Csizér (2009) conclude that those high school students who took part in their research had a positive attitude towards their language teachers and a positive opinion about the language classes in high school. In her study, Jenifara Zaman (2016) focuses on two factors that may affect language learning: motivation and ability. Theoretically, students with good language learning ability and higher motivation are better language learners than those who are poorly motivated. Results from Zaman's questionnaire show that the students had a high motivation because they could get better jobs knowing English. 
The factors presented above are all simultaneously influencing the motivation of foreign language learners. However, it needs to be highlighted that only some of the factors that are said to have the most significant influence on foreign language learning have been shortly presented above, and the researchers indicate many others besides the aforementioned, such as age and gender (Dörnyei, 2005).

\section{RESEARCH AIMS AND METHODOLOGY}

The present paper focuses on the foreign language learning motivation of students attending the Sapientia, Hungarian University of Transylvania, Faculty of Economics, Socio-Human Sciences and Engineering in Miercurea-Ciuc (Csíkszereda). The exploratory research involved the use of an online questionnaire. Applying the quantitative analysis, the study examines the factors influencing participant students' English language learning motivations. Thus, the present study aims to find out what type of English language learning motivation (integrative or instrumental) can be detected among the participant students and what motivational factors influence students' language learning the most.

The students who took part in the present study are all students of the Sapientia, Hungarian University of Transylvania, at the Faculty of Economics, Socio-Human Sciences and Engineering in Miercurea-Ciuc (Csíkszereda). Simple random sampling was employed when distributing the questionnaire with the use of social media (Facebook sharing) and email lists. The Faculty has a total of 671 students enrolled on BA studies and 178 students on MA studies. The total population of 103 students filled in the online questionnaire, 70 of which were female and 33 were male. The respondents most frequently belonged to the age group of 18 to 20 (35 respondents) and 21 to 25 (62 respondents). The questionnaire respondents were both undergraduate students of the university and Master's students. Most of the answers came from undergraduate students who were in their third year of university studies $(N=36)$, but there was a similar number of first-year students $(N=33)$ and second-year students $(N=24)$. Only 6 respondents attended MA studies, while 3 students were in their fourth year.

According to Dégi (2018), foreign languages have an important role in the Romanian educational system. Pupils in Romania usually study two foreign languages at school, most often English and French or German; in the case of the Hungarian minority students, it is rather German. Pupils start to learn English in the third grade, having one class each week; later, in the fifth grade, they start to learn French or German, having two foreign language classes each week. In high schools, students continue studying English, while the weekly number of classes depends on their profile (2-6 classes/week). Therefore, all the participants must have studied English before applying for the university. 
As it emerges from the results of the questionnaire, the majority of the respondents (58 students) has been studying English for 11 to 15 years; 30 students responded that they have been studying English for 6 to 10 years. For every student who studies at the faculty in Miercurea-Ciuc (Csíkszereda), it is obligatory to study English for four semesters, in groups according to the level of their English knowledge. Groups are created based on the students' high school language certificates. Before students take their final exams (state exam), they need to have a B2 language certificate in English (the university offers the possibility of taking the language exam locally, or the students can take an international English exam).

University students come from different regions of the country, mostly from the Hungarian speaking region of Transylvania. However, as the Faculty in Miercurea-Ciuc (Csíkszereda) is located in Harghita county, most of the university students come from Harghita county and its neighbouring counties, like Covasna and Mureş. Similar tendencies appear in our sample: most of the respondents came from Harghita county $(N=58)$, followed by Covasna county $(N=35)$ and Mureş county $(N=5)$.

Regarding the participants' self-assessment of their level of English, 23 of the respondents claimed to have an elementary level of English, 65 to have a pre-intermediate/intermediate level, and 15 to be proficient users of English. Most of the respondents did not have a language certificate $(N=67) ; 21$ of the respondents had a B2 certificate in English and 13 subjects had a B1 level, while only 2 respondents had a C1 certificate in English.

In order to gather data about the students' English language learning motivation, an online questionnaire was used. The questionnaire was created using Google Forms and it was distributed through email lists, private emails and Facebook, sharing it in the groups created for the university students. The questionnaire was written in Hungarian language and contained 60 questions, 9 out of which were demographical questions referring to the respondents' personal data (such as age, gender, academic year etc.). There was an open-ended question, which referred to the language learning strategies applied by the students in order to learn English, and 50 5-point Likert-scale statements $(1=$ strongly disagree and $5=$ strongly agree $)$, which all related to the students' motivations towards learning English. The 50 statements can be categorised into 7 different types of motivational factors. The statements and factors were created based on the research of Csizér and Dörnyei (2005), and Török and Csizér (2007). Moreover, Gonzales and Marco's study (2015) provided the basis for the categorisation of the statements used in the questionnaire. Seven different categories were created, each representing one motivational factor: Factor 1 (Instrumentality); Factor 2 (Desire to become a global citizen); Factor 3 (Ideal FL Self); Factor 4 (Desire for self-satisfaction); Factor 5 (Attitudes towards learning English); Factor 6 (Cultural integration); and Factor 7 (Ought-To Self).

Both quantitative and qualitative analyses were conducted to the data gathered through the online questionnaire. The results of the 5-point Likert 
scale statements were imported into Excel and then to SPSS statistical software in order to perform statistical analysis of the data. Beyond the general mean values and descriptive statistics, the significance of the results was also tested. The answers given to the open-ended question, referring to students' learning techniques and strategies, were analysed qualitatively using content analysis of the results provided.

\section{RESULTS AND DISCUSSION}

As a first step, the mean value of each statement was calculated in order to have a general overview of the answers and to see whether certain statements received very high or very low scores. From the results, it emerges that some statements received low scores ( 15 statements out of 50 with mean values under 3), meaning that participants disagreed with those statements; 25 statements had a rather neutral score, meaning that students neither agreed nor disagreed with those statements; and 10 statements received scores higher than 4 points, therefore it can be deduced that research participants agreed with those statements.

The questionnaire item which received the highest mean value (4.44) is statement no. 14- "I study English because it is a very important world language" - expressing participant students' desire to become global citizens.

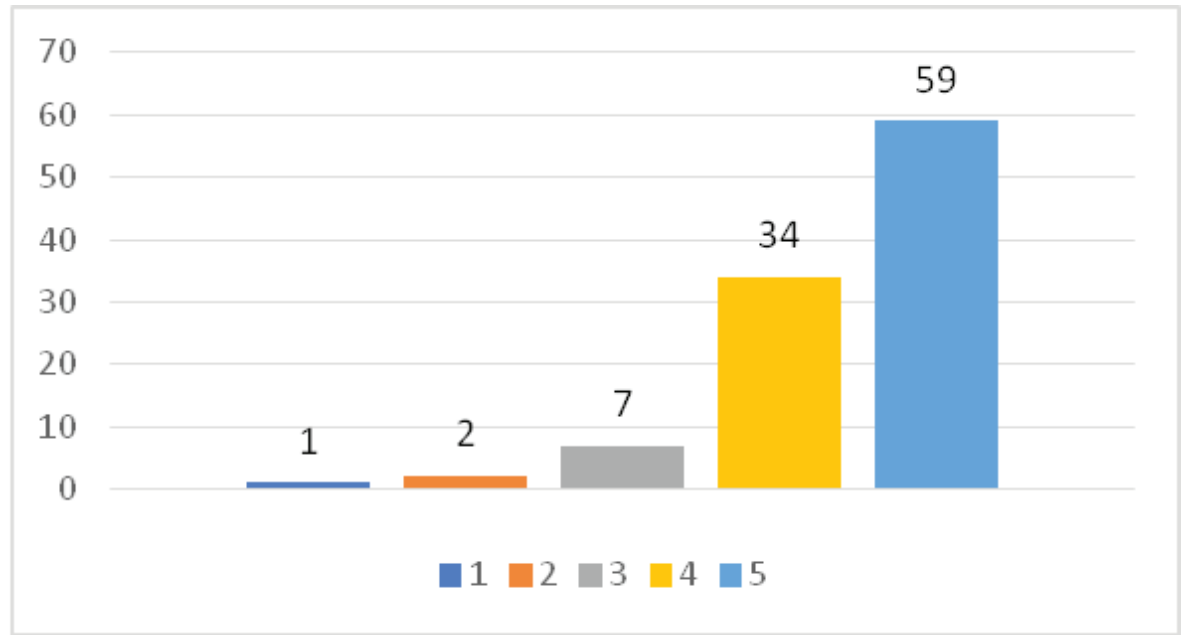

Fig. 1. Item 14 - "I study English because it is a very important world language."

Source: own research

As Figure 1 above shows, 90\% of the participants agreed with this statement: the majority $(70.87 \%)$ of the respondents strongly agreed with the statement that they study English because it is an important world language and only $0.97 \%$ of the respondents said that they do not study Eng- 
lish for this reason. The second highest score, with a mean value of 4.35 points, was given to the statement "It is very important for me to speak English," showing participants' attitudes towards speaking English and also their ideal-self.

The lowest mean value (2.14) was calculated for item no. 22, "I think that others expect me to speak English as a native speaker."

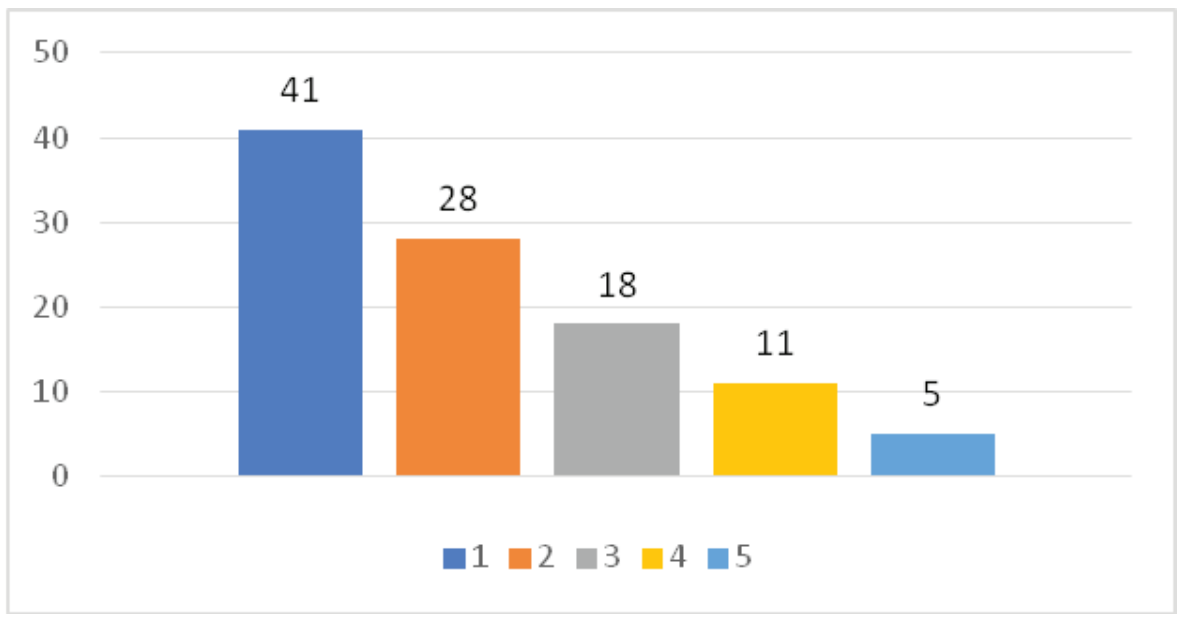

Fig. 2. Item 22 - "I think that others expect me to speak English as a native speaker." Source: own research

As it can be seen from Figure 2, over $67 \%$ of the respondents disagreed with this statement, meaning that students do not think other people expect them to speak English at a native-like level. Based on these answers, we can assume that students' ought-to-self does not involve speaking the language like a native speaker, or at least participants do not sense any expectation of this kind from the community, the teachers or the surrounding milieu. Statement no. 57 ("I have to get good grades, because, if I do not study hard, I think my parents will be disappointed with me") got the same lowest mean values (2.14) as statement no. 22.

Figure 3 below presents the mean values of each motivational factor, presenting the overall significance each factor has for the English language learning motivation of the participant students. 


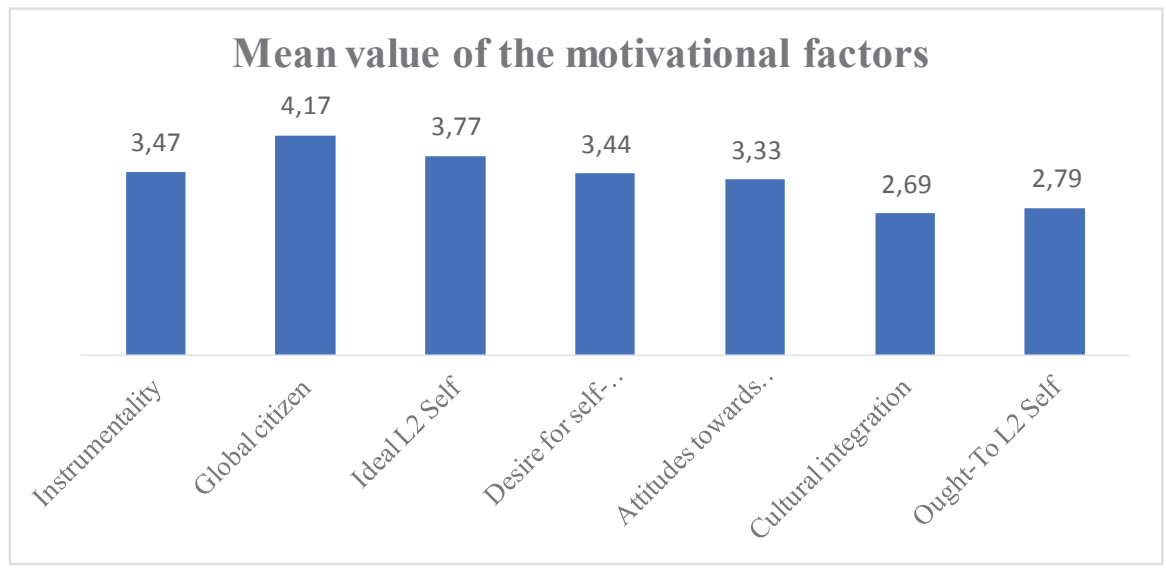

Fig. 3. Mean value of the motivational factors.

Source: own research

As it can be seen from Figure 3 above, Factor 2 (Desire to become a global citizen) had the highest mean value (4.17 points), while Factor 6 (Cultural integration) had the lowest (2.69 points). It is a very interesting result to see these two factors at the opposing ends of the participants' motivational continuum. Becoming a global citizen with all its underlying meanings, such as travelling, communicating with people from other countries, speaking a world/global language etc., is the greatest driving force and motivational power behind learning English. In contrast with such a cosmopolitan identity, cultural integration, i.e. integrating into the native speaker community, is the least significant motivational factor.

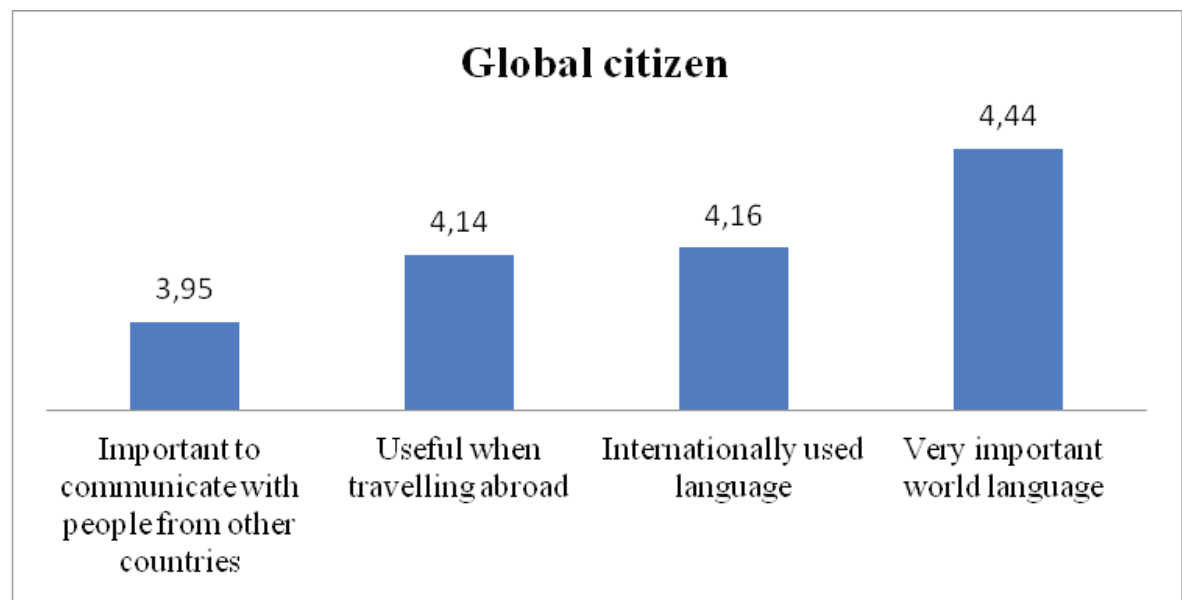

Fig. 4. Desire to become a global citizen.

Source: own research 
As Figure 4 above presents, there were 4 statements ascribed to the global citizen motivational factor, all of which exceeded 3 points; therefore, it can be concluded that participants agreed with all these statements and they are motivated to learn English because they consider English to be a key and widely used international language, which is useful when travelling abroad and in communicating with people from other countries. Following these results, it can be stated that the study participants would like to become global citizens, which lines with the results of Dörnyei's study (2005), in which he found that the majority of the youth develops a global language identity using the international media, TV and social media.

On the other hand, as seen in Figure 3, Cultural Integration scored the lowest mean values. In a similar vein to previous research studies mentioned in the theoretical part, university students participating in the present study were not significantly influenced by the integrative motivational factors (see Török \& Csizér, 2007; Carrió-Pastor \& Mestre Mestre, 2013). Dörnyei (2005) offered a possible interpretation explaining learners' low level of integrative motivation, namely that most learners are not in close contact with the target language speaking community (at least in the case of English). Therefore, learners do not want to identify with the target language speaking community but rather with the positive cultural and/or intellectual characteristics of the language. In this case, according to Dörnyei (2005), the English language is not connected to its native speakers but it becomes a global language inferring cosmopolitan and globalised identity.

The second highest positive score (3.77) was given to the Ideal FL-self category of motivational factor, which involves statements regarding how students imagine themselves in the future and what is the role or importance of English in this future image. Similarly to Tódor's (2009) and Fehér's (2012) research, the Ideal FL-Self factor received a relatively high mean value; therefore, it can be said that English plays an important role in students' future self-identity and students believe that they can reach a good/better level of English in the future.

Scores given for Instrumentality and Desire for self-satisfaction are very close: 3.47 and 3.44 respectively. Using English for watching TV, TV series, videos or movies offers self-satisfaction, but as the answers to the open-ended question also prove, students watch English videos, films and English language media in general to improve their language skills, which might also be linked to their instrumental motivations. The category of Instrumentality included 6 statements that belong to this motivational factor: two statements are related to university grades and exams, while 4 statements are connected to students' future career or job. As the results show, students are less motivated by grades or exams and they rather learn English to land a good job in the future. Out of the 6 statements, statement no. 59 ("I would like to learn English well to improve my chances of getting a well-paid job") got the highest mean value (4.14), whereas statement no. 37 ("I study English because it is important for me to have good grades at the university and to have a high mark in English") had the lowest mean value (2.44). 
The average score for Factor 5 (Attitudes towards learning English), i.e. 3.33, might be misleading. At the first glance, we might understand that students' attitudes towards learning English are not very positive; however, it emerges from the detailed responses that attitudes towards learning English and willingness towards putting effort into improving language skills received high scores..

Nevertheless, questionnaire results show that respondents are not satisfied with their English language skills (2.38) and believe that learning a foreign language is difficult for them (2.67). However, they are willing to put effort into learning English, as the mean value of this statement shows (4.1). Scores given to the statements within this motivational category are mostly between 2.40 and 4 points and many statements received points around 3, which means that students marked those statements neither very positive nor negative. Higher scores were given to the statement saying that they like English (3.96) and that they like English classes at the university (3.73). Compared to the scores given for high school English classes (2.94), students assigned higher scores to English classes at the university. Similarly to the results of the study carried out by Galántai and Csizér (2009), the respondents had a positive attitude towards the English language itself and towards the English classes. Furthermore, it is also interesting to see that students' volition to put effort into learning English received the highest score, but neither improving the language at the university (3.37) nor learning or practising the language outside the classroom got high scores (3.59). These results are rather surprising since, if we look at students' answers given to the open-ended question at the beginning of the questionnaire ("In order to learn English well, I use the following techniques, I do the following things: ..."), most respondents (55.33\%) stated that they watch movies in English (with or without subtitles) and $18.44 \%$ said that they watch TV series in English. The second most popular answer was reading books and short stories in English (33\%), while only 7.66\% of the respondents answered that they read the news/articles in English. Listening to music and occasionally reading the lyrics too was mentioned 18 times (17.47\%), 16 respondents mentioned playing video games $(15.53 \%)$ and 15 claimed that they regularly do exercises to improve their English grammar (14.56\%). 17 respondents stated that they use applications such as Duolingo and Ewa to improve their English knowledge $(16.5 \%)$.

The category of Ought-To Self received the second lowest mean value (2.72), most probably due to the age characteristics, since university students are less likely to be influenced or motivated by their parents' or other people's expectations or obligations. The scores indicate that respondents are neither motivated by their parents' attitude towards the importance of English in their future (2.37), nor by good grades (2.14). Moreover, students are not motivated by other people's possible expectations, or they disagree with the expectations of speaking native-like (2.14); at the same time, they disagreed with the statement saying that nobody cares if they learn English or not (2.31). 
Based on the low scores given to the statements within the ought-to-self category of motivational factor, it can be concluded that participant students are not motivated by other people's expectations or obligations. The significance of the ought-to-self motivational factors might be influenced by age, since Galántai and Csizér (2009) in their research on western Hungarian high school students found that the ought-to-self motivational factor does not significantly influence Hungarian students' language learning motivation, but Fehér (2012) who examined the motivation of seventh and eighth graders found that the ought-to self has a significant role as peer recognition and acknowledgement are very important at this age and learners try to fit into others' expectations even in language learning.

\section{CONCLUSION}

The aim of the present paper was to get an insight into the foreign language learning motivation of students attending the Sapientia, Hungarian University of Transylvania, Faculty of Economics, Socio-Human Sciences and Engineering in Miercurea-Ciuc (Csíkszereda). 103 students took part in the exploratory research where the online questionnaire was used and the results were subject to quantitative analysis.

The first research question aimed to find out the types of English language learning motivation (integrative or instrumental) that can be detected in the participant students. The results show that instrumental motivation has a strong effect on the surveyed students. Even though students are less likely to be motivated by good grades, they are highly motivated by the prospect of using the English language in the future. Students are motivated the most by the idea of getting a well-paying job with the help of their English knowledge, which is supported by the fact that out of the 6 statements belonging to the category of Instrumentality, all four questions referring to the respondents' future job/career scored over 3.5 points. Results also show that integrative motivation is not the most powerful motivational factor for the participant students; in fact, this motivational factor received the lowest score. From the 5 statements assigned to Cultural Integration, only one scored higher than 3 points, while the other four statements were below that. The lowest scores of all 50 statements were assigned to the motivational factor. Based on the responses, we can safely state that these students are not motivated by the idea of living in a country where they speak English nor would they like to be similar to the English-speaking people.

The second research question aimed to point out the motivational factors which influence students' language learning the most. As we could see in Figure 3 above, the Desire to become a global citizen is the most influential motivational factor with a mean value of 4.17 points and Cultural Integration scored lowest with a mean value of 2.69 points. For the respondents, it is greatly important to become part of the global society and a cosmopolitan citizen. 
Answers to the open-ended question related to the techniques students use to improve their English show that participants watch movies, TV series and YouTube videos in English, or read books in order to use the language when travelling abroad and communicating with people from other countries. The second most influential motivational factor is the Ideal FL-self with a score of 3.77 points. This category provides us with an insight into students' ideas about the importance of English in their future and how they see themselves speaking English in the future. The present paper thus leads to similar findings to the ones of Tódor's (2009) and Fehér's (2012), suggesting that English plays an important role in the students' image of their future selves and that they believe they can reach a high level of English in the future. Instrumentality received a score of 3.47 points and Desire for self-satisfaction amounted to 3.44 . In our view, these two statements scored similarly because there is a connection between them. Students use English as an instrument not only to get better jobs but also to watch TV, TV series and to play video games as well, which can be considered a hobby. Even though Factor 5 (Attitudes towards learning English) amounted to only 3.33, we know that students are willing to put effort into foreign language learning, in spite of the fact that they are not satisfied with their current English language knowledge. Ought-To Self motivational factor received the second lowest score (2.72), which could be explained by the respondents' age characteristics - at this age, students are not influenced by the expectations or opinions of their parents, families or even peers.

Moreover, respondents' answers reveal that even though they are not satisfied with their present knowledge of English, they like this language (3.96) and they are willing to put effort into learning English (4.10); simultaneously, they are not motivated by their marks, the obligation of a language exam, or by their parents' expectations. They watch TV, videos, and films in English to improve their language skills and they are mostly motivated by global mobility and their future career. Participant students do not want to integrate within a native speaking community and they do not want to speak the language as native speakers: they rather aim to become global citizens with English.

\section{REFERENCES}

[1] Bíró, E. (2012). Kétnyelvüek nyelvtanulási stratégiái [Learning strategies of bilinguals]. Kolozsvár: Egyetemi Múhely Kiadó, Bolyai Társaság.

[2] Carrió-Pastor, M. L., \& Mestre Mestre E. (2014). Motivation in second language acquisition. Procedia - Social and Behavioural Sciences, 116, 240-244.

[3] Chilingaryan, K. P., \& Gorbatenko R. (2015). Motivation in language learning. SGEM2015 Conference Proceedings, 2(1), 661-672. Retrieved April 16, 2019, from https://sgemsocial.org/ ssgemlib/spip.php?article1441

[4] Csizér, K., \& Dörnyei, Z. (2005). Language learners' motivational profiles and their motivated learning behaviour. Language Learning, 55(4), 613-659.

[5] Dégi, Zs. (2012). Types of multilingualism explored in the Transylvanian school context. Jezikoslovlje, 13(2), 645-666.

[6] Dégi, Zs. (2018). EFL classroom interaction from a multilingual perspective within the Transylvanian school context. [Unpublished doctoral thesis]. University of Szeged. 
[7] Dörnyei, Z. (2003). Attitudes, orientations, and motivations in language learning: Advances in theory, research, and applications. Language Learning, 53(1), 3-32.

[8] Dörnyei, Z. (2005). The psychology of the language learner. London: Lawrence Erlbaum Associated Publishers.

[9] Dörnyei, Z. (2014). Motivation in second language learning. In: M. Celce-Murcia, D. M. Brinton, M. A. Snow \& D. Bohlke (Eds.), Teaching English as a second or foreign language (pp. 518531). Boston: National Geographic Learning.

[10] Fehér, A. (2012). A motivált tanulási viselkedés vizsgálata általános iskolás nyelvtanulók körében. [Surveying motivated language learning process among Hungarian seventh and eighth graders] In: H. Hattyár, E. H. Hugyecz, V. Krepsz \& Zs. Vladár (Eds.), A sokszínü alkalmazott nyelvészet [Diverse applied linguistics] (pp. 13-19). Budapest: Tinta Könyvkiadó.

[11] Fernández Orío, S. (2013). Motivation and second language acquisition. Retrieved April 15, 2019, from https:/ / biblioteca.unirioja.es/tfe_e/TFE000342.pdf

[12] Galántai, D., \& Csizér, K. (2009). A tanár szerepe a diákok idegen nyelvi motivációjának alakításában [The teacher's role in the formation of foreign language learning motivation of the students]. Iskolakultúra, 19(9), 71-77.

[13] García Arce. A. (2016). The role of motivation in learning English as a second language: A case to study in the International School Eindhoven (The Netherlands). [Master's thesis, Univeristy of Oviedo]. Repositorio Institutional de la Universidad de Oviedo. http://hdl.handle. net/10651/38997

[14] Gardner, R. C. (2001). Integrative motivation and second language acquisition. In: Z. Dörnyei \& R. Schmidt (Eds.), Motivation and second language acquisition (pp. 1-19). Honolulu: University of Hawaii Press.

[15] Getie, A. S. (2020). Factors affecting the attitudes of students towards learning English as a foreign language. Cogent Education, 7(1), 1-37.

[16] Gonzales, R. D., \& Lopez, M. Y. (2016). Foreign language learning motivation questionnaire: further examination of a six-factor model [Unpublished manuscript]. Graduate School, University of Santo Tomas, Manila, Philippines. Retrieved April 15, 2019, from https:/ / www.researchgate. net/publication/269576750_Foreign_Language_Learning_Motivation_Questionnaire_Further_Examination_of_a_Six-Factor_Model

[17] Khasinah, S. (2014). Factors influencing second language acquisition. Englisia. Journal of Language, Education, and Humanities, 1(2), 256-269.

[18] Kontráné Hegybíró, E., Csizér, K., \& Piniel, K. (2015). Idegennyelv-tanulási motivációs tényezők rajzolata siket és nagyothalló diákokkal folytatott interjúk tartalmi elemzése alapján [The illustration of foreign language learning motivational factors created on the basis of interviews made with deaf and semideaf students]. In: T. Gecső \& C. Sárdi (Eds.), Nyelv, Kultúra, Társadalom (pp. 139-142). Budapest: Tinta Könyvkiadó.

[19] Taylor, F. (2013). Listening to Romanian teenagers: Lessons in motivation and ELT methodology. In E. Ushioda (Ed.), International perspectives on motivation (pp. 40-46). Basingstoke: Palgrave Macmillan.

[20] Tódor, E.-M. (2009). Többnyelvú lét, tanulási motivációk, tudásalapú társadalom [Being bilingual, learning motivation, knowledge-based society]. Új Pedagógiai Szemle, 59(4), 72-83.

[21] Török, D., \& Csizér, K. (2007). Nyelvtanulási motiváció az angol szakos egyetemisták körében [Language learning motivation in case of university students majoring in English]. Iskolakultúra, 17(11-12), 1-12.

[22] Ushioda, E. (2010). Motivation and SLA: Bridging the gap. Eurosla Yearbook, 10(1), 5-20.

[23] Ushioda, E. (2014). Motivation, autonomy and metacognition: Exploring their interactions. In D. Lasagabaster, A. Doiz \& J. M. Sierra (Eds.), Motivation and foreign language learning (pp. 31-49). Amsterdam/Philadelphia: John Benjamins Publishing Company.

[24] Zaman, J. (2015). Role of motivation in second language learning: A study of private university students in Bangladesh. [Master's thesis, BRAC University]. Bangladesh. http://hdl.handle. net/10361/4898 